\title{
Application of the LUminometric Methylatoion Assay for plant ecological researches: the study of global DNA methylation in leaves of Elodea canadensis under laboratory conditions and in leaves of fen orchid from wild populations
}

\author{
Natalja Škute ${ }^{1 *}$, Marina Savicka ${ }^{1}$, Aleksandrs Petjukevičs ${ }^{1}$, Nadežda Harlamova ${ }^{1}$ \\ Laboratory of Molecular Biology and Genetics, Institute of Life Science and Technology, Daugavpils University, \\ Parades Str.1A, Daugavpils, Latvia
}

\section{*Corresponding author: natalja.skute@du.Iv}

\section{Abstract}

The epigenetic changes in the genome of plants are one of the important regulatory mechanisms in response to the environmental factors. The LUminometric Methylation Assay (LUMA) requires a relatively small DNA amount, a short processing time and is easily adapted for species with a non-resolved genome. The LUMA has not been previously used for ecological research of plants. In this research, LUMA was used for the first time to investigate the changes of global DNA methylation under different environmental factors in the leaves of different plants. The influence of salinity on global DNA methylation was studied on aquatic macrophyte Elodea canadensis Michx, which grew in aquatic tanks under different $\mathrm{NaCl}$ concentrations. After the third week of growth, the Hpall/Mspl ratio was measured by LUMA and global DNA methylation percentages were calculated. The results showed salt stressinduced changes in the global DNA methylation level in E.canadensis leaves, compared to control. The response was salt dosedependent. The changes of global DNA methylation in wildlife plant populations were analogically assessed on fen orchid Liparis loeselii (L.) Rich. It was shown that global DNA methylation level was higher in leaves of these plants in Engure Lake, where there are temporary changes in water regime, compared to leaves of plants from other places. It was assumed that global GC-DNA methylation plays an essential role in the survival of this plant. Therefore, we show the possibilities of using the LUMA method for epigenetic study of different plants ecological researches.

Keywords: DNA methylation; Elodea canadensis (Michx.); epigenetics; LUminometric Methylation Assay; Liparis loeselii (L.) Rich.; salinity; wild populations.

Abbreviations: AFLPs_analysis based on Amplified Fragment Length Polymorphisms after PCR, CTAB_ hexadecyltrimethylammonium bromide, ELISA_enzyme-linked immunosorbent assay, HPLC-UV_high-performance liquid chromatography in ultraviolet, LUMA_The Luminometric Methylation Assay, LC-MS/MS_HPLC coupled with mass spectrometry, MSAP_analysis based on Methylation Sensitive Amplification Polymorphism, RFLP_Restriction Fragment Length Polymorphism.

Introduction

Epigenetic mechanisms regulate high-order DNA structure and gene expression without changes in the underlying DNA sequence. A best-known epigenetic modification is methylation of cytosine. It is a chemical modification, which covalently involves the addition of a methyl group onto the position 5 of a pyrimidine cytosine ring $(5 \mathrm{mC})$. DNA methylation in plant is different from animals. In plants, DNA methylation $(5 \mathrm{mC})$ is species-, tissue-, organelle- and agespecific (Vanyushin and Ashapkin, 2011). A relatively high degree of nuclear DNA methylation is specific feature of plant genomes. In the plant genome DNA methylation at the cytosine $\mathrm{C} 5$ position is the most abundant modification with up to $25 \%$ of the cytosine (Steward et al., 2002). It occurs not only at CG dinucleotides as in mammalian, but also in CNG and CNN trinucleotide sites (where $\mathrm{N}$ is $\mathrm{A}, \mathrm{T}$ or $\mathrm{C}$ ). Because of their symmetrical nature, CG and CHG methylation can simply be copied after DNA replication, but non-symmetrical $\mathrm{CHH}$ methylation has to be established de novo following each DNA replication cycle (Bartels et al., 2018). Usually, two main functions is targeted: firstly, gene expression regulation by methylation or demethylation at gene promoter and/or body sites, and secondly, protection of genome stability by silencing repeated sequences, such as transposable elements (Chan et al., 2005). DNA methylation has been hypothesized as an underlying mechanism of temporary changes in the phenotype (Suzuki et al., 2008). In recent years, it is known that pattern of DNA methylation in model plants is sensitive to various environmental stressors under laboratory conditions. The global DNA methylation is correlated with the response mechanism to various environmental changes such as salt stress, drought menace, and virus infection. The changes in DNA methylation occur under the influence of photoperiod and during fruit development and ripening (Dalakouras et al., 2010; Pan et al., 2009; Li et al., 2012; Kim et al., 2014). The level of DNA methylation varies in different ways depending 
on the stress to which plants are exposed. For example, a low-temperature exposure can decrease the levels of DNA methylation (Choi and Sano, 2007). However, the opposite effect has been reported for salt stress, and the effects of heavy-metal stress are species-specific (Labra et al., 2002; Peng and Zhang, 2009). The high concentrations of $\mathrm{NaCl}$ in the substrate can damage water plants on structural level by altering anatomical and physiological processes. However, plants can use several strategies to cope with high water salinity that all require a significant modulation in gene expression through different epigenetic processes (Yaish et al., 2017; Assaha et al., 2017; Al Kharusi et al., 2017). Aquatic macrophytes are the most important components of water bodies, which are sensitive to salinity causing a variety of physiological, biochemical and metabolic dysfunctions. Therefore, the model plant $E$. canadensis Michx was used in our research under laboratory conditions.

Plant ecologists have focused on the variation in DNA methylation in wild plant populations to understand the role of DNA methylation in plant adaptation to real environmental stress in nature (Lele et al., 2018; Bossdorf et al., 2008; Kilvitis et al., 2014). The study of populations of Vitex negundo var. heterophylla (Chinese chastetree) from adjacent habitat types at seven sampling sites suggests that epigenetic variation may complement genetic variation as a source of functional phenotypic diversity associated with adaptation to the heterogeneous habitat in natural plant populations (Lele et al., 2018). The broad taxonomic survey of global cytosine methylation in 279 species from two distant, ecologically disparate geographic regions supported that genome-wide global DNA cytosine methylation. It is a tractable "epiphenotypic" feature suitable to explore geography, evolutionary history, and ecological settings relationships (Alonso et al., 2019). The L. loeselii exists in different moist habitats eastwards in the temperate zone to central Siberia and intemperate boreal northern America. The broad geographic distribution of the L. loeselii (L.) species indicates adaptability, which is a consequence of possible epigenetic changes.

Many approaches are available for quantitative analysis of global genome DNA methylation. The 5-methylcytosine can be directly measured using chromatographic methods like HPLC-UV, LC-MS/MS. Although these methods are quantitative, they generally require large amounts of DNA, highly specialized equipment, and are generally difficult to standardize for use on large sample collections. Their major limitation has always been that they can only assess a small percentage of global DNA methylation. ELISA, AFLP and RFLP methods could be used for any species, even with limited or without information about their DNA sequence composition (Kurdyukov and Bullock, 2016). Recently, MSAP has been used for the study of global DNA methylation status of organisms (Yaish et al., 2014). However, this method is laborious and long running. LUMA holds great promise as a method for quantitative study of DNA methylation in organisms with a non-resolved genome. The LUMA requires only a relatively small amount of DNA and is permissive for genomic DNA methylation studies of any genome as it relies on use of methyl-sensitive and insensitive restriction enzymes, followed by polymerase extension via pyrosequencing technology (Karimi et al., 2006). This technology began to be used for the research in the field of human diseases (Bjornsson et al., 2008; McCullough et al.,
2015). There are even fewer scientific articles of using this method for the study of global DNA methylation under the influence of environmental factors on animals and on plant cells culture (Pilsner et al., 2010; Head et al., 2014; Berglund et al., 2017).

The aim of this article was to show the possibilities of using LUMA method for quantification of global DNA methylation in different plant ecological researches: evaluation of DNA methylation in model plant $E$. canadensis Michx, grown in laboratory condition in aquatic tanks with different concentrations of $\mathrm{NaCl}$, and in wild fen orchid populations of Liparis loeselii (L.) Rich, grown at the seashore area and continental region of Latvia.

Results

\section{Global DNA methylation in leaves of model plant $E$. canadensis}

The $E$. canadensis is one of the freshwater macrophytes species, which grows in brackish water occasionally only. Promotion of plant genome methylation might be one of the mechanisms that are used for developing tolerance to salt stress (Dyachenko et al., 2006). The global DNA methylation in leaf of elodea under different water salinity was studied by LUMA. The obtained data is shown in Fig 4. It was demonstrated that $E$. canadensis control samples in water tank without salt $(0.00 \mathrm{M} \mathrm{NaCl})$, the $\mathrm{Hpall} / \mathrm{Mspl}$ ratio was 0.79 . But the Hpall/Mspl ratio was $0.64-0.66$ in samples of $E$. canadensis in water with moderate salinity $(0.025 \mathrm{M}(\sim 1.45$ $\%$ ) and $0.05 \mathrm{M}$ ( 2.9\%). However, Hpall/Mspl ratio was 0.30 in samples of $E$. canadensis, grown in water under the $0.1 \mathrm{M}(\sim 5.8 \%$ o) salinity (Fig 4, A). The data show that the relative global GC-DNA methylation increased in $E$. canadensis leaves under the increasing water salinity. This relation was well described by a linear equation (Fig 4, B). The concentration $0.05 \mathrm{M} \mathrm{NaCl}$ corresponds to the water salinity in the Baltic Sea. Our data demonstrate that Hpall/Mspl ratio not substantially varies in samples of $E$. canadensis at this water salinity level $(0.025 \mathrm{M} \mathrm{NaCl}$ and $0.05 \mathrm{M} \mathrm{NaCl}$ ). We can assume that enzymatic GC-methylation of $E$. canadensis genome is stable for this water salinity level.

\section{Global DNA methylation in leaves of fen orchid L. loeselii wild populations}

The orchid family is one of the most threatened plant families in Latvia. Plant samples of L. loeselii, were taken from six habitats in Latvia: at the seaside area, and at the more continental region, at the east part of Latvia. The Hpall/Mspl ratio in DNA from leaves of $L$. loeselii measured by LUMA was shown in Fig 4. The Hpall/Mspl ratio differred from 0.54 in leaves of $L$. loeselii from Lake Engure to 0.73 from Lake Pelecu. However, this ratio $(0.69 \pm 0.03)$ varied insignificantly among all these lakes (except Lake Engure). Accordingly, the Hpall/Mspl ratio in DNA from leaves of $L$. loeselii, grown in Lake Engures differed from others by $21 \%$ (Fig 4, A). It was found that the relative global DNA methylation level of DNA varied also insignificantly between the habitats in seaside and continental regions from $35 \%$ to $27 \%(31 \pm 1.5 \%)$ (Fig 4, B). However, a relative global methylation level of DNA was significantly higher (46\%) in leaves of $L$. loeselii from Lake Engure. 


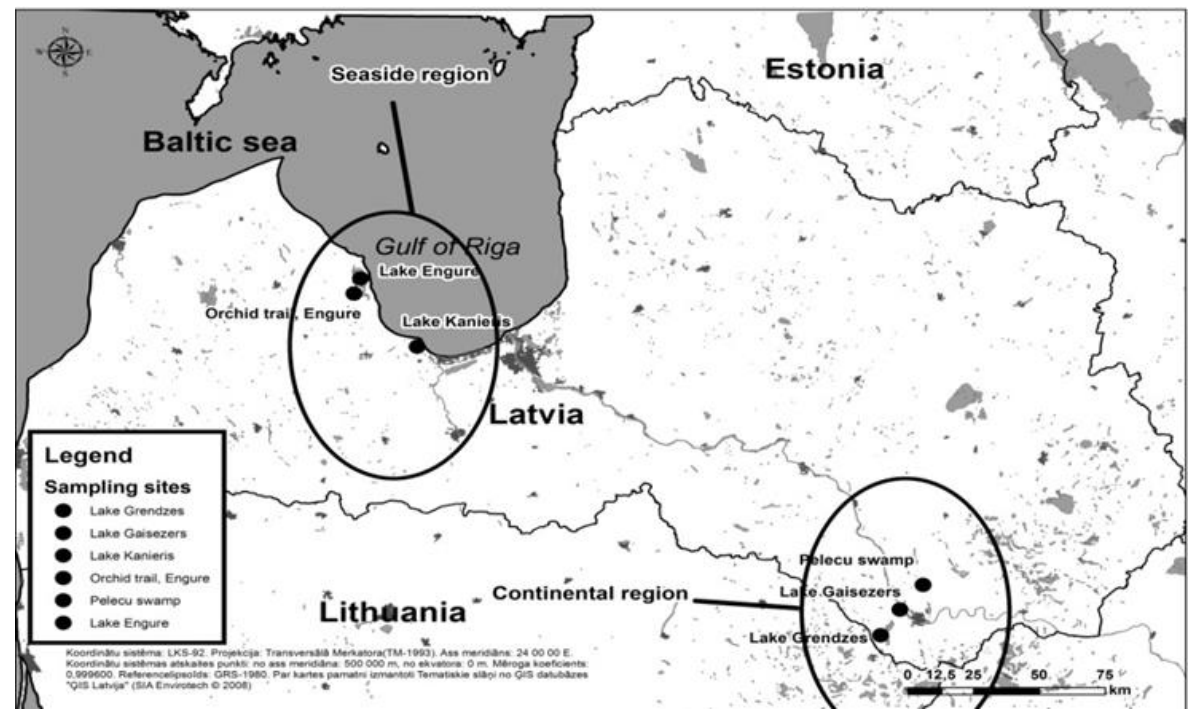

Fig 1. The location of sampling zones of Liparis loeselii (L.) Rich. in Latvia

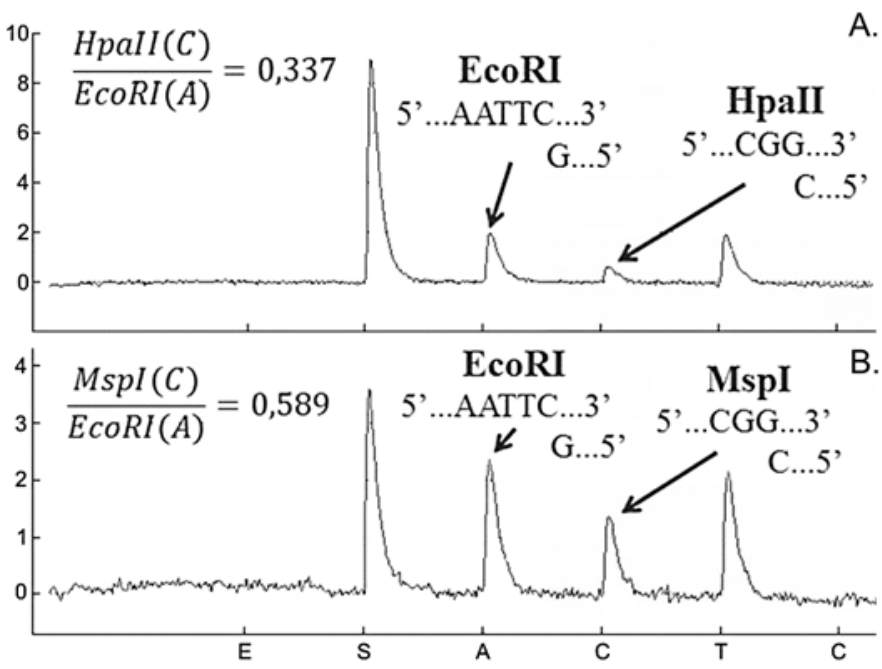

Fig 2. Typical LUMA read-out of the Pyrosequencing reactions, using genomic DNA isolated from leaves of Elodea canadensis (A) Digestion reaction with restriction enzymes Hpall and EcoRI, (B) Digestion reaction with restriction enzymes Mspl and EcoRI.
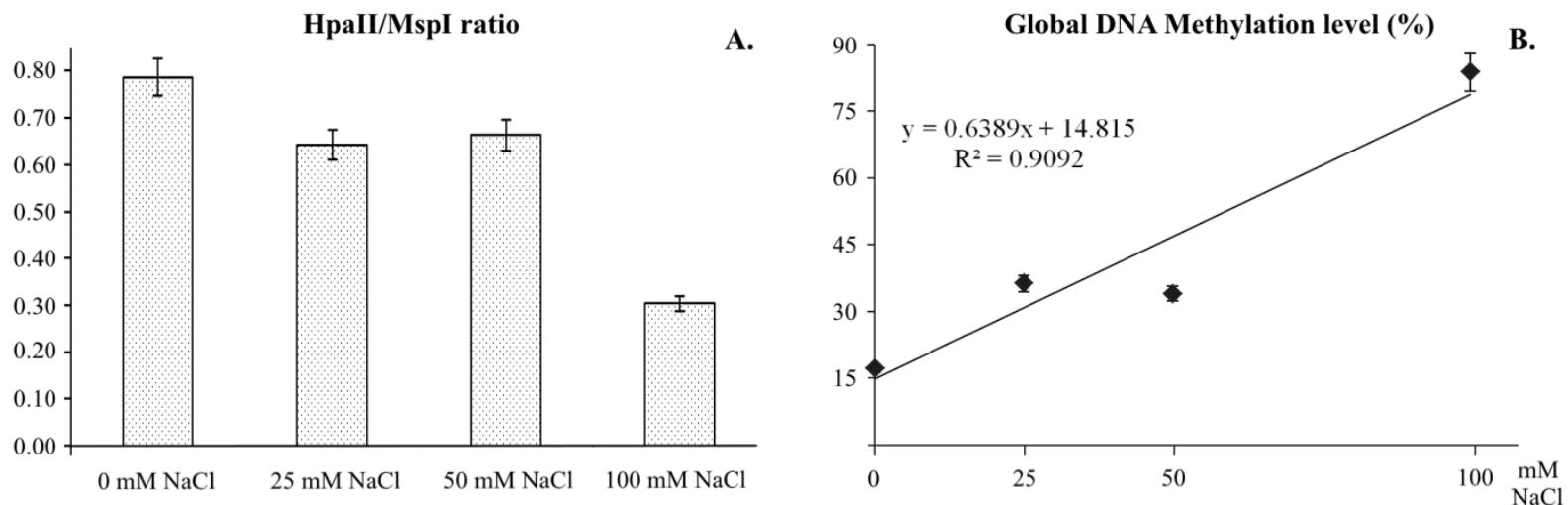

Fig 3. The global DNA methylations changes of E. canadensis leaves under the different salinity level: (A) Hpall/Mspl ratio in DNA. The results presented as mean values \pm standard error, with three replications, (B) Regression between the level of salt ( $\mathrm{NaCl}$ ) concentration (mM), and global DNA methylation level (\%). 

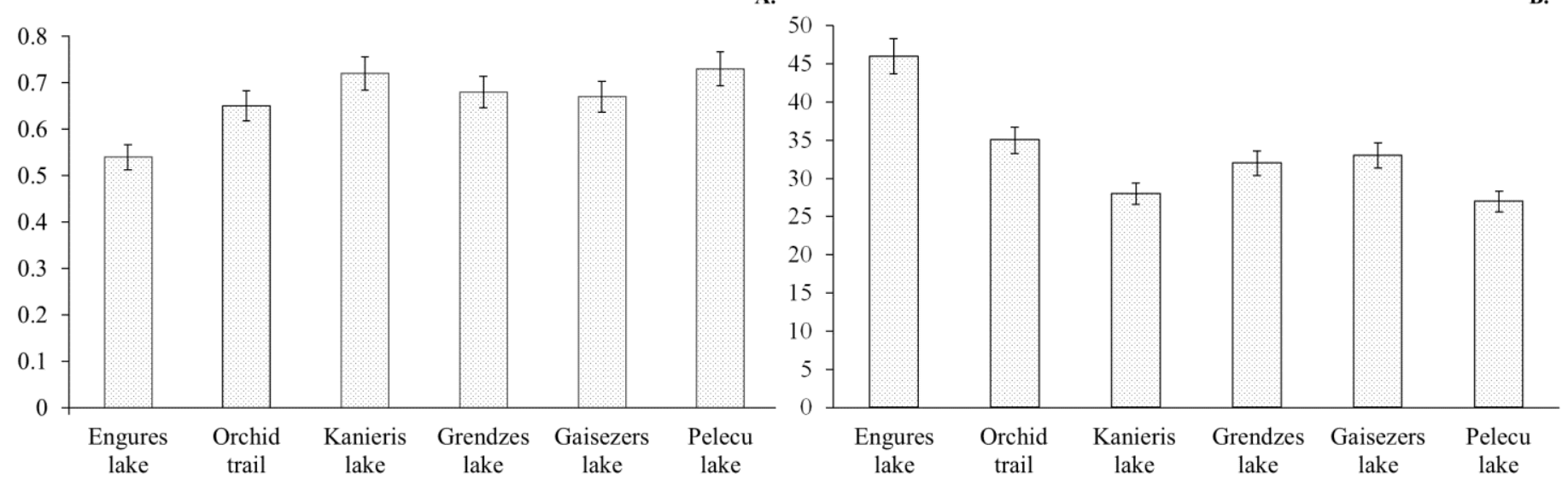

Fig 4. The global GC-DNA methylation changes in leaves of L. loeselii from different zones of Latvia: (A) Hpa II/Mspl ratio and (B) global DNA methylation level (\%). The results presented as mean values \pm standard error with three replications.

\section{Discussion}

\section{Global DNA methylation in leaves of model plant $E$. canadensis}

Plants can use several strategies to cope with high water salinity that all require a significant modulation in gene expression through different epigenetic processes (Yaish et al., 2018). Global DNA hyper-methylation was also detected in pea root tip (Pisum sativum L.) under the water deficit conditions by MSAP method. It was observed an increase in the methylation level of both cytosine residues in CCGG motifs, especially for the inner cytosine (Labra et al., 2002). An increase in cytosine methylation at CCGG sites was detected in different plants, which include both de novo methylation and demethylation events. However, salt stress can also cause demethylation at specific loci (Guangyuan et al., 2007). The MSAP was performed in oil seed rape plants subjected to salt stress and three types of bands were defined. Extensive changes in the types of MSAP bands were observed after treatment with $100 \mathrm{mM} \mathrm{NaCl}$. These included the appearance and disappearance of all types of band, as well as exchange between band types. However, there was no change in the methylation of the cytosine of CG dinucleotides, as revealed by digestion with Mspl and Hpall (Kovarik et al., 1997), which may be due to the loci that located in a heterochromatic region, having a high background level of methylation.

The $E$. canadensis have invaded numerous aquatic ecosystems in the Europe and is well-represented in coastal marshes, where they exhibit different tolerances to different water salinity. During the tides, salt water from the Baltic Sea (3.5-4.0\%o) gets to the Lake Kisezers near Riga. Our data shows that the relative global GC-DNA methylation was increased in $E$. canadensis leaves under the increasing water salinity. The high concentrations of $\mathrm{NaCl}$ can affect the physiological processes in E. canadensis (Petjukevics et al., 2015). Promotion of plant genome methylation might be one of the mechanisms that are used to develop tolerance to salt stress (Dyachenko et al., 2006). DNA hypermethylation may be a plant protective mechanism that induces cell cycle arrest with the consequent reduction of plant growth and development (Labra et al., 2004). E. canadensis plants are genetically homogeneous populations and in Western Europe there are only female specimens. The same genotype in situations of external stress manifests a pronounced epigenetic plasticity. Changes in plant genome methylation might be one of the mechanisms that are used to develop tolerance to salt stress.

\section{Global DNA methylation in leaves of fen orchid L. loeselii wild population}

The orchid family grows eastwards in the temperate zone to central Siberia and intemperate, boreal northern America except Alaska (Roze et al., 2014). L. loeselii range occurs in different moist habitats: wet and sandy lakeshores and meadows, fens, ditches, old fields, abandoned peat excavations and gravel pits, forested wetlands. The broad geographic distribution of the species indicates its adaptability. The genetic variations in most cases might be neutral. It might not impact genomic function, but the epigenetic variation could have a direct impact on genome function, and through this might affect the fitness of an organism to specific environmental condition. However, the lack of information about the heritable epigenetic variation and its influence on local adaptation in natural populations are observed. This orchid species is dependent on a constant hydrological regime (Roze et al., 2014). When temporary changes in water regime, such as flooding or a drop in the water level occurs, the species does not flower and can survive in a vegetative stage. When the changes are permanent, the species disappear after three or four years. The bogging of the shore of Lake Engure creates new suitable habitats for $L$. loeselii as an early successional species. The survival of $L$. loeselii in wet habitats with fluctuating water level is ensured by various adaptations. In this research, we found that DNA methylation plays an essential role in the survival of the L. loeselii in Lake Engures. Although LUMA is very sensitive to low-quality DNA and measures only $\mathrm{CpG}$ methylation within the recognition of sequences of the restriction enzymes (CCGG), this method is fast and convenient for different ecological researches of plants. 


\section{Materials and methods}

\section{Objects of investigation}

Leaves of Elodea canadensis (Michx.) were used for investigation of water salinity influence on global DNA methylation by LUMA method in laboratory conditions. The leaves of 3-year-old fen orchid Liparis loeselii (L.) Rich. from two different zones of Latvia were used to evaluate the possibility of using the LUMA method to understand influence of environmental factors on global DNA methylation in wild plant populations.

\section{Plant growth conditions and sample collecting zones}

Aquatic macrophytes $E$. canadensis were cultured in glass tank under laboratory conditions in climate chambers (POLEKO, Poland), a photoperiod regime: $8 \mathrm{~h} / 16 \mathrm{~h}$ (dark/light) cycle, light intensity: $50 \mu \mathrm{mol}$ photons $\mathrm{m}^{-2} \mathrm{~s}^{-1}$, temperature: $18^{\circ} \mathrm{C} / 15 \pm 1.0^{\circ} \mathrm{C}$ (day/night). The tap water after filtration in water tanks was prepared with following concentrations of $\mathrm{NaCl}: 0.00 \mathrm{M}, 0.01 \mathrm{M}$ (0.58 \%o), 0.025M (1.45\%), 0.05M $(2.9 \%$ ) and $0.1 \mathrm{M}(5.8 \%) \mathrm{NaCl}$. It was known that $E$. canadensis tolerates salinities up to $2.5 \%$ (Sand-Jensen, 2000). After the third week of growth in glass tank with different water salinity, the leaves of $E$. canadensis were cut and stored at $-80^{\circ} \mathrm{C}$.

Fen orchid L. loeselii (L.) Rich. samples were taken from six habitats in Latvia: Lake Kaniera, Lake Engure, Orchid trail (which are located at the seaside area, at the Gulf of Riga), Lake Grendzes, Lake Gaisezers, and Pelecu swamp (which are located at the more continental region of Latvia) (Fig 1). The leaves of 3-year-old $L$. loeselii were cut and stored at $80^{\circ} \mathrm{C}$. Methylated DNA is very stable, but the DNA fragmentation can be problematic for LUMA (Head et al., 2014). Therefore, storage conditions of plants are very important for this method.

\section{DNA isolation}

The correct method for DNA extraction is very important for quantitative global DNA methylation analysis using LUMA. Previous epigenetic studies, focused on DNA methylation, have assumed that methyl groups are not lost during routine DNA extraction, but this has not been empirically tested. Many different methods and technologies with different protocols are available for DNA isolation. The selection of method depends on several factors, such as DNA quality, purity and others. Regardless of the method used, DNA samples may be exposed to varying degrees of oxidative conditions. DNA oxidation could occur during isolation by the presence of oxidants in cells or by those produced by cell lysis (Kvam and Tyrrell, 1997; Guetens et al., 2002). Different levels of oxidation during the extraction procedure could decrease the methylation level. Our data demonstrate that LUMA is very sensitive to low-quality DNA and DNA fragmentation level. The extent of fragmentation of the DNA sample is influenced by the isolation method. The review of LUMA results from the studies of human blood shows differences around $20 \%$ between DNA chloroform extraction and column isolation kits (Soriano-Tarraga et al, 2013). As others have noted (Ammerpohl et al., 2009) LUMA is more sensitive to poor DNA quality than other methods for determining CpG methylation rates (such as HPLC or bisulphite sequencing) because the presence of singlestranded overhangs in degraded DNA can contribute to the LUMA signal.

Previously some DNA isolation methods were examined: $C T A B$, salting-out method, extraction with column isolation kits "DNeasy Plant Mini Kit" (data not shown). The column isolation kits "DNeasy Plant Mini Kit" (Qiagen) was the most appropriate method for high-quality DNA isolation. This isolation method is preferred by other researchers (Head et al., 2014). All samples also were treated with RNase A (100mg/ml, Qiagen).

\section{DNA quality and quantity}

DNA was quantified spectrophotometrically (Shimadzu BioSpec-Nano) at A260/A280 and A260/A 230, A260/A280 $\sim 1.8$, and A260/A $230 \sim 1.9$, respectively (Wilfinger et al., 1997). DNA quality was checked by agarose gel electrophoresis $(1.5 \%)$ in TBE buffer and gels were stained with ethidium bromide $(0.5 \mu \mathrm{g} / \mathrm{mL})$. The size of DNA fragments was determined by comparing with DNA ladders of known size (100bp DNA Ladder Plus, MBI Fermentas). For this study, only the high-molecular DNA was used. It was shown that even slightly fragmented samples can depress DNA methylation values when analysed by LUMA

\section{Luminometric Methylation Assay (LUMA)}

LUMA is a method to estimate genome-wide DNA methylation and requires a relatively small DNA amount (250-500 ng). It has short processing time and can be easily adapted to multiple species. The LUMA has the advantage that can be used with the DNA from various species without extra optimization. However, it is sensitive to a number of factors, such as DNA quality and the choice of isoschizomers used for cutting DNA in a methylation-sensitive manner.

The method based on a polymerase extension assay using the Pyrosequencing ${ }^{\mathrm{TM}}$ platform (PyroMark Q24), with PyroMark Gold Q reagents was used. All steps were performed based on the original method according Karimi et al. (2006).

Restriction enzymes (Hpall, Mspl, and EcoRI) and Tango buffer for digestion reaction (final volume $20 \mu \mathrm{l}$ ) were used. PyroMark Gold Q24 Reagents (Qiagen) were used for luminometric methylation assay. The Hpall/Mspl ratio can be defined as (Hpall/EcoRl)/ (Mspl/EcoRl). Methylation percentages were calculated as: 1-[(Hpall(C) /EcoRI(A)) $/(\mathrm{Mspl}(\mathrm{C}) / \operatorname{EcoRI}(\mathrm{A}))] \times 100$. The unmethylated DNA produces Hpall/Mspl ratio close to 1.0. In the methylated DNA, the ratios are close to zero. The typical LUMA readouts from the Pyrosequencing reactions with genomic DNA from leaves of E. canadensis were shown in Fig 2. DNA was digested in parallel reactions with EcoRI (recognition site G/AATTC) and isoschizomeric restriction enzymes, Hpall or Mspl. Both cleave at the recognition site $5^{\prime}$...C/CGG...3', but Hpall cuts only when the internal $C$ is unmethylated, whereas $M s p l$ is insensitive to methylation status at the internal $C$. The $A$ and $T$ peaks denote the additions of dATP $\alpha$ S and dTTP respectively. The nucleotides of which are substrates for filling in all EcoRI generated T and A overhangs.

Thus, the dTTP-peak serves as a control for the dATP-peak, which in turn, is used as the internal control peak of the 
assay, A and T peaks should be equal. dCTP and dGTP are added together, and the corresponding peak denotes Hpall or Mspl cleavage. The second C peak is a control for completion of the first $\mathrm{C}$ peak and should be close to zero. The peak designated " $\mathrm{S}$ " is the substrate peak representing the starting point of Pyrosequencing reactions. Cells-to-CpG Methylated gDNA control kit (Applied Biosystems) was used as a high-methylated control, but sample without DNA as a control of nucleotide degradation.

\section{Acknowledgments}

This study has been partially supported by the National Research Programme 2014-2017 „EVIDEnT” sub-project 4.6. "Freshwater ecosystems services and biological diversity”. Thanks Dr. D. Roze for orchid samples.

\section{References}

Al Kharusi L, Assaha DV, Al-Yahyai R, Yaish MW (2017) Screening of date palm (Phoenix dactylifera L.) cultivars for salinity tolerance. Forests. 8(4):136.

Alonso C, Medrano M, Pérez R, Canto A, Parra-Tabla V, Herrera CM (2019) Interspecific variation across angiosperms in global DNA methylation: phylogeny, ecology and plant features in tropical and Mediterranean communities. New phytol. 224(2):949-960.

Ammerpohl O, Martın-Subero Jl, Richter J, Vater I, Siebert R (2009) Hunting for the 5th base: techniques for analyzing DNA methylation. Biochim Biophys Acta. 1790:847-862.

Assaha DVM, Ueda A, Saneoka H, Al-Yahyai R, Yaish MW (2017) The role of $\mathrm{Na}+$ and $\mathrm{K}+$ transporters in salt stress adaptation in glycophytes. Front Physiol. 8:509.

Bartels A, Han Q, Nair P, Stacey L, Gaynier H, Mosley M, Huang Q, Pearson J, Hsieh T-F, An Y-Q, Xiao W (2018) DNA Methylation in Plant Growth and Development. Int J Mol Sci. 19(7):2144.

Berglund T, Wallström A, Nguyen TV, Laurell C, Ohlsson AB (2017) Nicotinamide; antioxidative and DNA hypomethylation effects in plant cells. Plant Physiol Biochem. 118:551-560.

Bjornsson HT, Sigurdsson MI, Fallin MD, Irizarry RA, Aspelund T, Cui $\mathrm{H}, \mathrm{Yu}$ W, Rongione MA, Ekström TJ, Harris TB, Launer L, Eiriksdottir G, Leppert MF, Sapienza C, Gudnason V, Feinberg AP (2008) Intra-individual change in DNA methylation over time with familial clustering. JAMA. 299(24):2877-2883.

Bossdorf O, Richards CL, Pigliucci M (2008) Epigenetics for ecologists. Ecol Lett. 11(2):106-115.

Chan SW, Henderson IR, Jacobsen SE (2005) Gardening the genome: DNA methylation in Arabidopsis thaliana. Nat Rev Genet. 6:351-360.

Choi CS, Sano H (2007) Abiotic-stress induces demethylation and transcriptional activation of a gene encoding a glycerophosphodiesterase-like protein in tobacco plants. Mol Genet Genomics. 277(5):589-600.

Dalakouras A, Moser M, Krczal G, Wassenegger M (2010) A chimeric satellite transgene sequence is inefficiently targeted by viroid-induced DNA methylation in tobacco. Plant Mol Biol. 73:439-447.

Dyachenko O, Zakharchenko N, Shevchuk T (2006) Effect of hypermethylation of CCWGG sequences in DNA of Mesembryanthemum crystallinum plants on their adaptation to salt stress. Biochemistry (Moscow). 71(4):461-5.

Guangyuan L, Xiaoming W, Biyun C (2007) Evaluation of genetic and epigenetic modification in rapeseed (Brassica napus) induced by salt stress. J Integr Plant Biol. 49(11):1599-607.

Guetens G, De Boeck G, Highley M, van Oosterom AT, De Bruijn EA (2002) Oxidative DNA damage: Biological significance and methods of analysis. Crit Rev Clin Lab Sci. 39:331-457.

Head JA, Mittal K, Basu N (2014) Application of the Luminometric methylation assay (LUMA) to ecological species; Tissue quality requirements and a survey of DNA methylation levels in animals. Mol Ecol Resour. 14(5):94352.

Karimi M, Johansson S, Ekström TJ (2006) Using LUMA: a Luminometric-Based Assay for Global DNA-Methylation. Epigenetics. 1(1):46-49.

Kilvitis HJ, Alvarez M, Foust CM, Schrey AW, Robertson M, Richards L (2014) Ecological Epigenetics. Adv Exp Med Biol. 781:191-210.

Kim K, DoBaidouri MEL, Jackson SA (2014) Accessing epigenetic variation in the plant methylome. Brief Funct Genomics. 13:318-327.

Kovarik A, Koukalova B, Bezdek M (1997) Hypermethylation of tobacco heterochromatic loci in response to osmotic stress. Theor Appl Genet. 95(1):301-6.

Kurdyukov S, Bullock M (2016) DNA Methylation Analysis: Choosing the Right Method. Biology. 5:3.

Kvam E, Tyrrell RM (1997) Induction of oxidative DNA base damage in human skin cells by UV and near visible radiation. Carcinogenesis. 18(12):2379-2384.

Labra M, Ghiani A, Citterio S (2002) Analysis of cytosine methylation pattern in response to water deficit in pea root tips. Plant Biol. 4:694-9.

Labra M, Grassi F, Imazio S (2004) Genetic and DNAmethylation changes induced by potassium dichromate in Brassica napus L. Chemosphere. 54(8):1049-58.

Lele L, Ning D, Cuiping P, Xiao G, Weihua G (2018) Genetic and epigenetic variations associated with adaptation to heterogeneous habitat conditions in a deciduous shrub. Ecol Evol. 8:2594-2606.

Li X, Zhu J, Hu F, Ge S,Ye M, Xiang H (2012) Single-base resolution maps of cultivated and wild rice methylomes and regulatory roles of DNA methylation in plant gene expression. BMC Genomics. 13:300.

McCullough LE, Chen J, White AJ (2015) Global DNA Methylation, Measured by the Luminometric Methylation Assay (LUMA), Associates with Postmenopausal Breast Cancer in Non-Obese and Physically Active Women. J Cancer. 6(6): 548-554.

Pan YZ, Gao W, Yu AM (2009) MicroRNAs regulate CYP3A4 expression via direct and indirect targeting. Drug Metab Dispos. 37:2112-2117.

Peng H, Zhang J (2009) Plant genomic DNA methylation in response to stresses: Potential applications and challenges in plant breeding. Pro Nat Sci-Mater. 19:1037-1045.

Petjukevičs A, Batjuka A, Škute N (2015). The impact of different levels of sodium chloride on the quantitative changes of chlorophyll and carotenoids in chloroplasts of Elodea canadensis (Michx. 1803). Biologija. 61(1):34-41.

Pilsner JR, Lazarus AL, Nam DH, Letcher RJ, Sonne C, Dietz R, Basu N (2010) Mercury-associated DNA hypomethylation 
in polar bear brains via the Luminometric Methylation Assay: a sensitive method to study epigenetics in wildlife. Mol Ecol. 19(2):307-14.

Roze D, Jakobsone G, Megre D, Belogrudova I, Karlovska A (2014) Survival of Liparis loeselii (L.) Rich. as an early successional species in Engure Region described based on ecological peculiarities during the annual cycle. Proc Latv Acad Sci Sect B Nat Exact Appl Sci. 68(1-2):93-100.

Sand-Jensen K (2000) An introduced vascular plant - the Canadian waterweed (Elodea canadensis). In: Weidema I (ed.) Introduced species in the Nordic countries. NordTema. 13:96.

Soriano-Tarraga C, Jimenez-Conde J, Giralt-Steinhauer E, Ois A, Rodriguez-Campello A (2013) DNA isolation method is a source of global DNA methylation variability measured with LUMA. Experimental analysis and a systematic review. PLoS ONE. 8(4):e60750.

Steward N, Ito M, Yamakuchi $\mathrm{Y}$, Koizumi N, Sano $\mathrm{H}$ (2002) Periodic DNA methylation in maize nucleosomes and demethylation by environmental stress. J Biol Chem. 277:37741-37746.
Suzuki Miho M, Bird A (2008). DNA methylation landscapes: provocative insights from epigenomics. Nat Rev Genet. 9:465-476.

Vanyushin BF, Ashapkin VV (2011) DNA methylation in higher plants: Past, present and future. Biochim Biophys Acta. 1809:360-368.

Wilfinger WW, Mackey K, Chomczynski P (1997) Effect of pH and ionic strength on the spectrophotometric assessment of nucleic acid purity. BioTechniques. 22:474-481.

Yaish M, Al-Lawati A, Al Harrasi I, Patankar H (2018) Genome-wide DNA Methylation analysis in response to salinity in the model plant caliph medic (Medicago truncatula). BMC Genomics. 19(1):78.

Yaish MW, Patankar HV, Assaha DV, Zheng Y, Al-Yahyai R, Sunkar R (2017) Genome-wide expression profiling in leaves and roots of date palm (Phoenix dactylifera L.) exposed to salinity. BMC Genomics. 18(1):246.

Yaish MW, Peng M, Rothstein SJ (2014) Global DNA methylation analysis using methyl-sensitive amplification polymorphism (MSAP). Methods Mol Biol. 1062:285-98. 